\title{
Postharvest Physiology, Biochemistry and Quality Management of Chili Plum (Spondias purpurea var. Lutea): A Review
}

\author{
Majeed Mohammed ${ }^{1}$, Puran Bridgemohan ${ }^{2}$, Owen Graham ${ }^{1}$, Lynda Wickham ${ }^{1}$, Ronell S. H. Bridgemohan ${ }^{3}$ \& \\ Zareef Mohammed ${ }^{4}$ \\ ${ }^{1}$ Department of Food Production, Faculty of Food and Agriculture, University of the West Indies, Trinidad \\ ${ }^{2}$ Biosciences Agriculture and Food Technology, The University of Trinidad and Tobago Waterloo Research \\ Campus, Carapichaima, Trinidad \\ ${ }^{3}$ Georgia College and State University, GA, USA \\ ${ }^{4}$ University of Miami, USA \\ Correspondence: Majeed Mohammed, Department of Food Production, Faculty of Food and Agriculture, \\ University of the West Indies, Trinidad. E-mail: majeed.mohammed@sta.uwi.edu
}

Received: February 28, 2019 Accepted: March 7, 2019 Online Published: March 15, 2019

doi:10.5539/jfr.v8n3p1 URL: https://doi.org/10.5539/jfr.v8n3p1

\begin{abstract}
The chili plum (Spondias purpurea L.) is an exotic fruit with a climacteric pattern of respiration belonging to the Anacardiaceous family and is consumed in both the fresh and processed states. The fruit has a yellow pulp, pleasant aroma, sweet sour taste with vitamin A content being higher than cashew, guava, some papaya and mango cultivars. However, a relatively short shelf-life of 5-6 days at ambient temperatures for harvested fruits and widespread incidence of fruit-fly infestation are two major limitations for increased utilization of this fruit. Fruits can be successfully stored up to 14 days at $12.5^{\circ} \mathrm{C}$. Fruits stored at $12.5^{\circ} \mathrm{C}$ and then subsequently transferred to $30-32^{\circ} \mathrm{C}$ ripened normally with a shelf-life of 4 days. Storage at temperatures below $9-10^{\circ} \mathrm{C}$ resulted in the occurrence of chilling injury damage accompanied by an inhibition of ripening. Chili plums have a caloric density of $74 \mathrm{kcal} / 100 \mathrm{~g} \mathrm{~g}^{-1}$ edible portion which is significantly higher than the 39 to $58 \mathrm{kcal} / 100 \mathrm{~g}^{-1}$ for peach, apricot, and mango and cherry. The higher caloric density is attributed to its total carbohydrates of $19.1 \%$ and fructose, glucose and sucrose which together account for $65 \%$ of the soluble matter. Unlike the other fruits, chili plum retains a fair amount of starch in the mesocarp. It is a moderate source of potassium $\left(250 \mathrm{mg} / 100 \mathrm{~g}^{-1}\right.$ edible portion) and an excellent source of vitamin C $\left(48 \mathrm{mg} / 100 \mathrm{~g}^{-1}\right.$ edible portion). Analysis of volatile flavour compounds showed 2-hexenal to be the main flavour compound present.
\end{abstract}

Keywords: chili plum, postharvest, respiration, ethylene, packinghouse

\section{Introduction}

The chili plum (Spondias purpurea L) is a member of the Anacardiace family, native to Mexico with a distribution inclusive of the Caribbean, Central America and Peru and Brazil, where it is also known as 'Lapa', 'Job', 'Moyo', 'Sta Roseno', 'Jismoyo' and 'De Cocer' (Barbeau, 1994; Mohammed, 2011; Maldonado-Astudillo et al., 2014). It is a is a tropical species whose physiological, anatomical, and agronomic plasticity allows it to adapt to a wide range of soil conditions and is tolerant of varying altitudes and temperatures (Maldonado-Astudillo et al., 2016). The yellow chili plum has high commercial potential due to its relatively low production cost and its adaptability to tropical soils (Avitia-Garcia et al., 2000). The fruits are consumed fresh with high acceptability throughout the Caribbean and Latin America, and demonstrated its potential for commercial largescale production (Bridgemohan, 2008). Information about the particular characteristics of different genotypes is sparse, mainly because their cultivation is still largely based on traditional agricultural practices such as backyard gardens, hedgerows, and small farms (Cuevas, 1994), as well the tendency of the crop to be prolific in the wild (Maldonado-Astudillo et al., 2014). Fruits are seasonal, highly perishable, often displayed for sale in heaps under ambient conditions at roadside outlets and municipal markets and susceptible to fruit fly infestations and fruit-rot fungi in the field. The postharvest quality of the fruit is influenced by the plant genotype and its edaphoclimatic conditions. The fruits are pre-disposed to several pre-and postharvest factors such as the maturity index (phenological, physical or chemical), the harvest method 
(manual or mechanical), transport and storage conditions (temperature, humidity, ventilation, etc.) and the conditions of product manipulation.

Currently, there is heightened interest in the consumption of functional foods (fruits and vegetables) associated with the prevention of chronic diseases. The beneficial effects of chili plums are amplified due to the presence of bioactive compounds (vitamins, enzymes, carotenoids, flavonoid, and phenols) which are rich in antioxidant properties (Hooper \& Cassidy, 2006; Isabelle et al., 2010). The utilization of the fresh fruit or processed forms must be explored in order to penetrate international markets since the fruits have the capacity to neutralize harmful molecules such as free radicals, that interact and destabilize important macromolecules like proteins, nucleic acids and lipids causing degenerative diseases (Niva, 2007). Accordingly, this review focusses on all aspects of the physiology and biochemistry of yellow chili plums and to examine the various preharvest and postharvest management procedures to optimize quality. This information is critical for the realization of the full potential of this fruit which has unique flavour and is a rich source of nutraceuticals.

\section{Morphology and Structure}

The tree attains a height of 3-10 m with a grayish smooth bark. The trunk is stout, with thick spreading branches and the leaves are pinnate $2.5-6.5 \mathrm{~cm}$ long with 5-23 leaflets. The flowers are solitary or fascicled in the axils of the fallen leaves. The plant is deciduous and defoliate during the early dry season as it enters the pre-floral stage. Flowering is stimulated by water stress (Bridgemohan \& Mohammed 2019). This characteristic has been attributed to its specific mechanism of defoliation which gives the plant the ability to spontaneously grow in, and adapt to poor soils (Avitia et al., 2000; Maldonado-Astudillo et al., 2014). The mature fruit is a smooth and shiny ellipsoid drupe that measures $2.5-4.0 \mathrm{~cm}$ in length and $1.5-2.5 \mathrm{~cm}$ in diameter. At different stages of maturity, fruits are consumed fresh, frozen, or processed into diverse food products such as pickles and candies. The epicarp is thin, has a smooth to semi-smooth texture, and upon maturity, can acquire a yellow colouration. The fruits have a thick and fibrous endocarp with the mesocarp giving the fruit its flavour quality characteristics which ranges from sour to sour-sweet coupled with a delectable aroma. This unique feature is embraced by consumer appeal and acceptance. The moderate levels of vitamin $\mathrm{C}$, potassium and calcium together with antioxidant compounds such as phenols and carotenoids contribute to the chemo-preventive potential of chili plum fruits (Sameh et al., 2018).

\subsection{Worldwide Importance and Economic Value}

Yellow chili plum is a tropical fruit with increasing acceptance in both national and international fruit markets (Bridgemohan, 2008). Mature trees produce several thousand fruits with an average yield per tree ranging from 40-50 kg (Barbeau, 1994). Koziol \& Macia (1998) examined the economic aspects of chili plum production in Ecuador and reported 1800 hectares are under cultivation with production of 4,500 metric tonnes of fruits. They estimated 10,000 metric tonnes would be required for industrial processing of the fruit to be commercially viable. Production levels below 4,500 metric tonnes per year would therefore limit commercial possibilities to processing at the level of a cottage industry or small industrial scale.

Mature-green harvested chili plum fruits ripen in 4-5 days and have a short shelf life of an additional 2-3 days. Tree-ripened fruits have a shelf life of just 1-2 days after harvesting. The limited shelf-life combined with the fruits susceptibility to physical damage during transport make international exportation of fresh chili plums very challenging and restricted. Macia \& Barfod (2000) described the sale of fresh chili plums to have impacted negatively to the income of small-scale producers in Ecuador because the majority of the profits are absorbed by middlemen who purchase and transport fruits in bulk to markets in the larger cities. Macia \& Barfod (2000) argued that for the assurance of any economic potential for chili plum, farmers would have to focus on "value-added products" rather than on the sale of fresh fruits. Macia \& Barfod (2000) justified this claim by highlighting an example whereby small farmers were paid US $\$ 0.10-0.30$ per $\mathrm{kg}$ for fresh chili plums whereas a $300 \mathrm{~g}$ jar of chili plum jam could be sold for US $\$ 1.45$. With production costs for such a jam roughly estimated at US $\$ 1.00$ per $\mathrm{kg}$, the small farmers profit could increase to about US $\$ 3.83$ per $\mathrm{kg}$ of processed chili plum fruits.

\subsection{Culinary Uses, Nutritional Value and Health Benefits}

The yellow chili plum pulp is an important source of potassium and copper (Tiburski et al., 2011). The antioxidant activity and total phenolic values scored $17.5 \mathrm{mmol}$ TEAC $\mathrm{g}^{-1}$ and $260 \mathrm{mg}$ galic acid/100g, respectively, and is higher than most tropical fruits. Five carotenoids were identified, $\beta$-cryptoxanthin, lutein, zeinoxanthin, $\alpha$ and $\beta$ carotene, with $\beta$-cryptoxanthin being dominant and accounting for the high level of pro-vitamin A activity in the pulp (Tiburski et al., 2011). The carotenoid content is lower than that of mango (Mangifera indica $\mathrm{L}$.) var. Tommy Atkins $\left(50.5 \mathrm{~g}^{-1}\right)$ whose most abundant carotenoid is violaxanthin, red guava (Psidium guajava) (56.6-69.7 $\mathrm{g}^{-1}$ ) or tomato (Solanum lycopersicum) $\left(43.9 \mathrm{~g}^{-1}\right)$, with lycopene being the most 
abundant carotenoid in these last two species (Rodríguez-Amaya, 1999; Tiburski et al., 2011). The main carotenoid in the pulp of chili plum is cryptoxanthin, $\left(17.08 \mathrm{~g}^{-1}\right)$ and zeinoxanthin $\left(3.52-5.47 \mathrm{~g}^{-1}\right)$, although, carotene, phytoene, phytofluene, and cryptoflavin have also been identified as precursors (Hamano and Mercadante, 2001; Rodríguez-Amaya, 1999; Tiburski et al., 2011). In fruits of the Spondias purpurea ecotype 'Cuernavaqueñaa', the total carotenoid content increases during ripening, with a greater concentration present in the epicarp (skin) compared to the pulp. A similar pattern was found in other fruits, including yellow chili plum (Rodríguez-Amaya, 1999). Recently, Sameh et al. (2018) reported that plants belonging to the genus Spondias were widely used in traditional medicine due to their beneficial therapeutic effects. Diverse pharmacological activities include cytotoxic, antioxidant, ulcer protective, hepatoprotective, anti-inflammatory, antiarthritic, and antidementia effects. These attributes are supportive of their potential to treat various degenerative diseases (Sameh et al., 2018).

The importance of phenolic compounds in Spondias fruit are natural antioxidants against chronic-degenerative diseases, but this compound also has a tendency to induce browning during processing and affects the flavour of the fruit (Engels et al., 2012; Filgueiras et al., 2001; Tiburski et al., 2011). A 100g portion of yellow plum pulp can provide more than $37 \%$ of the recommended daily allowance of vitamin A. The chili plum fruit weight is distributed in the seed (34\%), peel (8\%) and pulp (50-58\%) (Leung \& Flores, 1961; Winton \& Winton, 1935). Chili plum fruits according to Koziol \& Macia (1998) have the highest energy value when compared to other popular fruits such as apricot, cherry, peach and mango and this is attributed principally to its higher concentrations of total carbohydrates. The total concentrations of the three sugars sucrose $\left(5.9-7.2 \mathrm{~g} / 100 \mathrm{~g}^{-1} \mathrm{edible}^{-}\right.$ portion), fructose $\left(2.5 \mathrm{~g} / 100 \mathrm{~g}^{-1}\right)$ and glucose $\left(2.0 \mathrm{~g} / 100 \mathrm{~g}^{-1}\right)$ account for $65 \%$ of the total soluble solids measured as ${ }^{\circ}$ Brix. The fibre content is uncharacteristically low $\left(0.2-0.7 \mathrm{~g} / 100 \mathrm{~g}^{-1}\right)$, while there is a considerable amount of starch in the unripe fruit $\left(8.4 \mathrm{~g} / 100 \mathrm{~g}^{-1}\right)$ which is about 4 times higher than the ripe fruit. The free sugars and starch are easily fermentable and have an advantage for the development of an effervescent wine (Koziol \& Macia, 1998). Despite the low pectin content $\left(0.22 \mathrm{~g} / 100 \mathrm{~g}^{-1}\right)$, it is still sufficient for making a jam without the addition of more pectin. Given the acidity of the fruit $(\mathrm{pH}$ of 3.3) and the formation of jams without additional gelling agent, it is most likely that native pectins are of the high methoxyl type, that is, with degrees of esterification in excess of 50\% (Mitchell et al., 1978).

Chili plums are a moderate source of potassium (100-300 mg per serving) (Guthrie, 1979). Thus 100g edible portion of chili plums would provide $63 \%$ of the potassium requirements for children $4-6$ years old, $44 \%$ for children 7-10 years old, $16 \%$ for adolescents 11-14 years old, $12 \%$ for adolescents $15-18$ years old and 10\% for adults (Koziol \& Macia., 1998).

The vitamin C content of chili plums according to Koziol \& Macia (1998) is the highest compared to apricot, cherry, peach, mango. Accordingly, a 100g edible portion would provide 98-123\% of the recommended dietary allowance (RDA) for children 1-14 years old and 82\% of the RDA for people over 14 years old. The nutritional composition of the fruit includes: protein $(0.9 \%)$, fat $(0.24 \%)$, ash $(0.7 \%)$, total carbohydrates $(18.1 \%)$, calcium $(17 \mathrm{mg})$, iron $(0.30 \mathrm{mg})$, sodium $(9 \mathrm{mg})$, phosphorus $(42 \mathrm{mg})$, zinc $(20 \mathrm{mg})$, carotene $(119 \mathrm{mg})$, thiamine $(84 \mathrm{mg})$, riboflavin $(40 \mathrm{mg})$, niacin $(1.0 \mathrm{mg})$, citric acid $(30 \mathrm{mg})$, malic acid $(110 \mathrm{mg})$, oxalic acid $(30 \mathrm{mg})$, tartaric acid (20 mg) (Koziol \& Macia., 1998).

\section{Postharvest Physiology}

\subsection{Fruit Growth, Development and Maturation}

Filgueiras et al. (2001) reported that fruit weight of chili plums increased from $13.62 \mathrm{~g}$ to $14.05 \mathrm{~g}$ when predominantly green to $15.91 \mathrm{~g}$ when ripened or predominantly yellow. They also reported that fruit length and width are greatest when fruits are ripe. The percentage seed however decreases during growth and development with fruits at the yellow stage having $18.4 \%$ while at the earlier stages of development when predominantly green it is $20.58-23.63 \%$. Fruit pulp density increase with fruit maturity at the yellow ripe stage $(81.58 \%)$ compared to the green stages of development (75.71-79.41\%).

\subsection{Respiration and Ethylene Production}

Sampaio et al. (2007) investigated the respiratory activity and associated changes in chemical constituents during maturation of chili plums. They reported that the pre-climacteric was marked by the initial production of $24.4 \mathrm{ml}$ $\mathrm{kg}^{-1} \mathrm{~h}^{-1} \mathrm{CO}_{2}$ and initial oxygen absorption of $25.5 \mathrm{ml} \mathrm{kg}^{-1} \mathrm{~h}^{-1}$. The minimum evolution of $\mathrm{CO}_{2}$ was $11.0 \mathrm{ml} \mathrm{kg}^{-1} \mathrm{~h}$ ${ }^{-1}$ while the minimum absorption of $\mathrm{O}_{2}$ was $15.5 \mathrm{ml} \mathrm{kg}^{-1} \mathrm{~h}^{-1}$ after 102 and 108 hours, respectively, after harvest thereby confirming a climacteric minimum. The maximum liberation of $\mathrm{CO}_{2}$ of $54.2 \mathrm{ml} \mathrm{kg}^{-1} \mathrm{~h}^{-1}$ and $\mathrm{O}_{2}$ absorption of $49.0 \mathrm{ml} \mathrm{kg}^{-1} \mathrm{~h}^{-1}$ occurred at 186 hours after harvest thereby defining the climacteric peak. They also calculated the respiratory quotient of chili plums (RQ) at the pre-climacteric, climacteric minimum, 
climacteric peak and post-climacteric to be $0.96,0.63,1.11$ and 0.59 , respectively. Accordingly, the RQ value of 1.11 at the climacteric peak represented the oxidation of carbohydrates while the 0.96 accounted for the oxidation of proteins and the 0.63 and 0.59 indicated consumption of lipids.

In previous studies, Graham et al. (2001) reported an overall suppression of respiration for chili plums stored at $4-5^{\circ} \mathrm{C}$ and $9-10^{\circ} \mathrm{C}$, but at $20-21{ }^{\circ} \mathrm{C}$ and $30-31{ }^{\circ} \mathrm{C}$ respiration increased inducing ripening in 3-4 days (Figure $1 \mathrm{~A}$ and $1 \mathrm{~B}$ ). At $20-21^{\circ} \mathrm{C}$, immature and half-ripe fruits exhibited a more pronounced climacteric peak in comparison to mature-green and turning or breaker fruits. However, they did not observe the respiratory climacteric in fully-ripened fruits compared to fruits harvested immature, mature-green, turning or ripe. In more recent studies, Vargas et. al. (2017) observed no significant differences in $\mathrm{CO}_{2}$ production among the different ripening stages, with the average rate of respiration being $1.11 \mathrm{ml} \mathrm{kg} \mathrm{h}^{-1}$. In an earlier study, Pérez et al. (2004) did not observe significant differences in the respiration rate of Mexican plum fruit at three different ripening stages: green, $1 / 2$ yellow, and 3/4 yellow. Similar responses were articulated by Kohatsu et al. (2011) on Spondias purpurea fruit grown in Brazil. In contrast, Dantas et al. (2016), Montalvo-González et al. (2011), Pareíra et al. (2000) and Osuna et al. (2011) reported a climacteric behavior in Mexican plums grown in Mexico and Brazil. Maldonado-Astudillo et al. (2014) indicated that due to the variation in the behavior of $\mathrm{CO}_{2}$ production, it is difficult to determine if Mexican plum is a climacteric fruit although physical and biochemical changes during ripening suggest it is a climacteric fruit. They also reported an increase evolution of ethylene for immature, mature-green and turning fruits with the occurrence of a peak in ethylene production between days 3 to 5 at $20-21^{\circ} \mathrm{C}$ followed by a rapid decline thereafter. Peak ethylene production preceded peak $\mathrm{CO}_{2}$ production rates for immature and turning chili plums. Vargas et. al. (2017) also claimed that ethylene production increased at ripening from 3.92 to $9.43 \mu \mathrm{kg} \mathrm{h}^{-1}$, with the highest production observed in the fully ripe stage. Likewise, Montalvo-González et al. (2011) detected a significant increase in ethylene production during ripening of yellow chili plum under different light conditions. In general, an increase in ethylene production acts as a trigger to fruit ripening, inducing the autocatalytic production that causes changes in colour, texture, aroma, flavour, and other biochemical, physiological and physical attributes of the fruit (Hiwasa-Tanase \& Ezura., 2014) that the consumer consider important for consumption.

$\mathrm{C}_{2} \mathrm{H}_{4}$ production rates also increased significantly $(\mathrm{P}<0.001)$ for immature, mature-green and turning fruits, peaking between $3-5$ days of storage at $20-21^{\circ} \mathrm{C}$ followed by a rapid decline (Figure 1C). Peak $\mathrm{C}_{2} \mathrm{H}_{4}$ production rates preceded peak $\mathrm{CO}_{2}$ production rates for immature and turning fruits (Graham et al., 2001). 

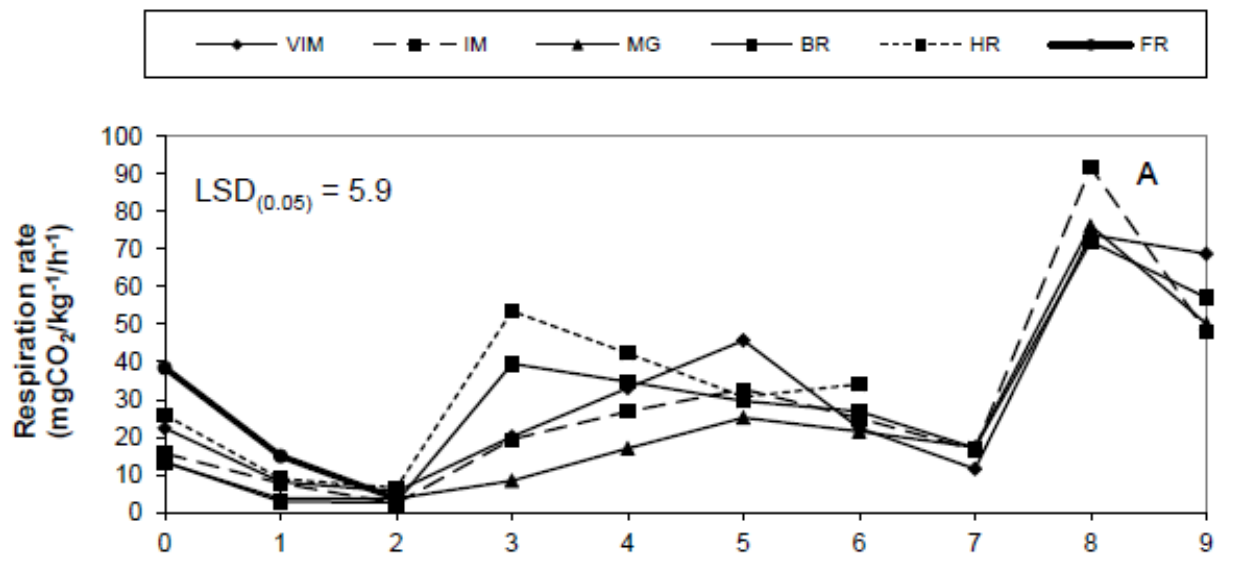

Days in storage

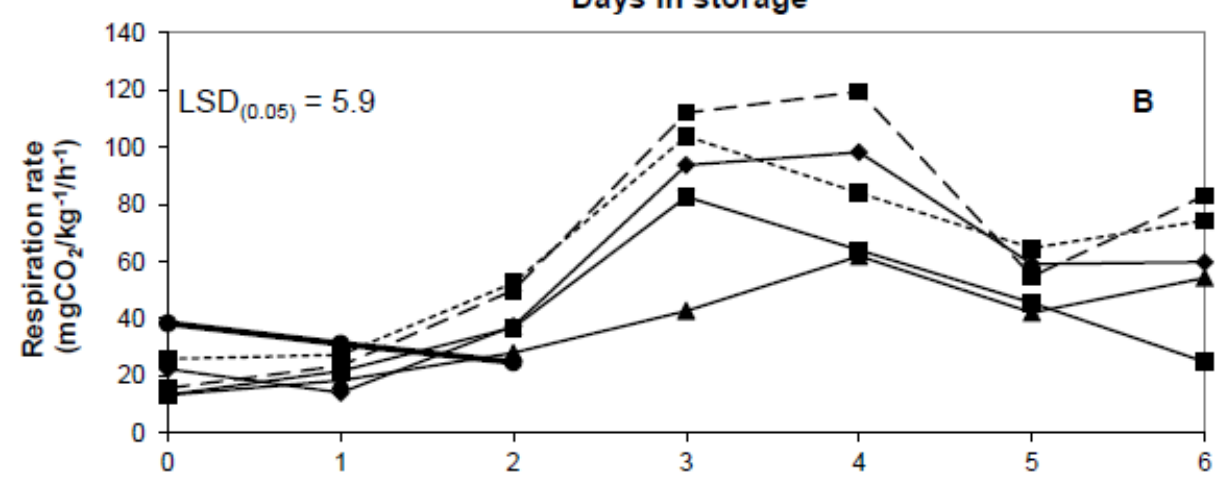

Days in storage

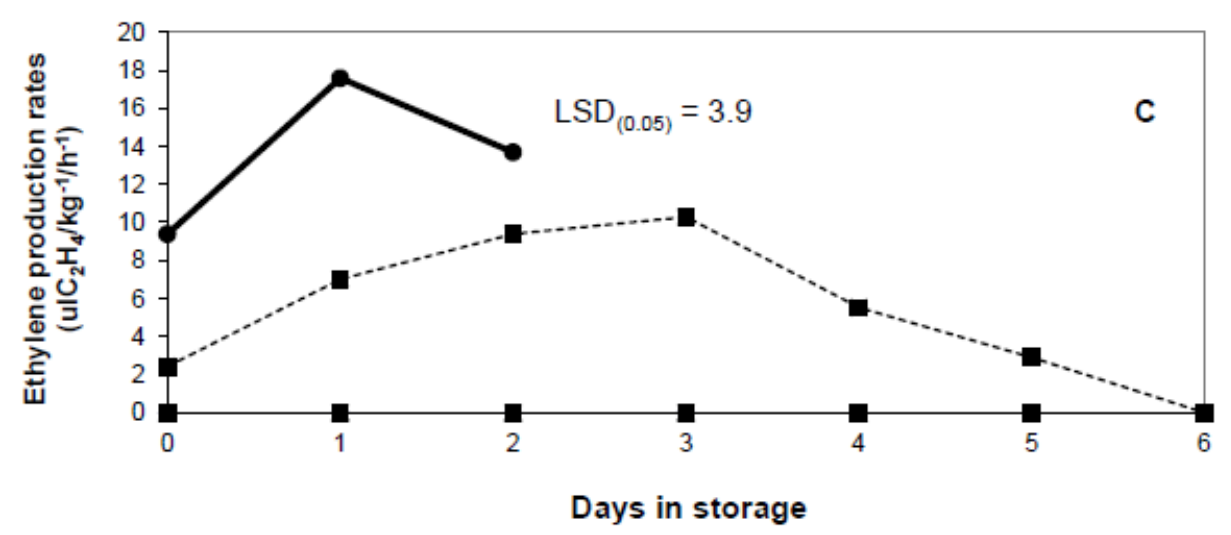

Figure 1. Changes in the respiration and ethylene production rates of chili plum fruits during storage

(A) Fruit stored at $9^{\circ} \mathrm{C}$, (B) fruit stored at $20^{\circ} \mathrm{C}$ and (C.) fruit stored at $20^{\circ} \mathrm{C}$. VIM= very immature fruit, IM= immature fruit, $\mathrm{MG}=$ mature-green fruit, $\mathrm{BR}=$ breaker fruit, $\mathrm{HR}=$ half-ripe fruit and $\mathrm{FR}=$ full-ripe fruit. Levels of significance were $(\mathrm{P}<0.001)$ for respiration and ethylene production rates respectively (Graham et al., 2001).

\subsection{Physicochemical Changes during Ripening}

Physicochemical changes of the mature-green chili plums during storage at $27.8-29.2^{\circ} \mathrm{C}$ was reported by Sampaio et al., (2007). They attributed that total soluble solids (TSS) increased from $9.1{ }^{\circ}$ Brix at the mature-green stage to $13.7^{\circ}$ Brix at the climacteric peak. At the same time, total titratable acidity (TTA) decreased during maturation and ripening from $1.35 \%$ initially to $1.31 \%$ at pre-climacteric, $1.0 \%$ at climacteric peak and eventually to $0.8 \%$ at the post-climacteric stage. This decrease in organic acids as ripening progressed suggested the involvement of the acids as a source of energy during respiration (Coombe, 1976; Kader, 1986). Noteworthy, is the total acid content of $1.30 \%$ and $1.49 \%$ in ripened chili plum fruits in earlier studies reported 
by Oliveira et al. (1999) and Bora et al. (1991). In their study, Sampaio et al. (2007) commented on the TSS-TTA ratio as increasing significantly at each stage in the climacteric curve while the opposite occurred for vitamin $\mathrm{C}$ content. Previously, Graham et al. (2001) provided evidence of increased total sugars and reducing sugar content, increased $\mathrm{pH}$ values and vitamin $\mathrm{C}$ content as ripening progressed. There was also increased softening in turning fruits compared to immature and mature-green fruit, and decreased TTA in more mature fruits over time. They concluded these changes to the breakdown of complex polysaccharides and subsequent conversion into simple sugars which normally occurs in many ripening fruits. In the same study, it was also articulated that fruits stored at $30-31^{\circ} \mathrm{C}$ had lower total and reducing sugars content than those stored at $20-21^{\circ} \mathrm{C}$ after 5 days. Fruits stored at $30-31^{\circ} \mathrm{C}$ had higher rates of respiration and consequently a much faster depletion of soluble sugars.

The behavior of chlorophyll pigments of chili plums during ripening decreased while carotenoids exhibited a continuous decrease as a result of changes in $\mathrm{pH}$, presence of the oxidation system and the activity of chlorophyllase (Sampaio et al., 2007). The sequence of colour changes of the chili plum peel showed a transformation from an initial dark green to light green at the climacteric minimum; from light green to orange yellow during the climacteric rise in respiration and maintenance of an orange yellow colour during the climacteric peak and senescence.

Colour parameters in the epicarp of Mexican plum showed significant $(\mathrm{P}<0.05)$ changes among the four ripening stages (Vargas et al., 2017), similar to that reported by Dantas et al. (2016). The colour measurements of the green stage revealed that the epicarp was green $(h o=108.9)$, dull $\left(\mathrm{C}^{*}=26.4\right)$ and slightly bright $\left(\mathrm{L}^{*}=39.9\right)$ compared to the $1 / 2$ green stage which was close to yellow (ho=93.7), less dull $\left(\mathrm{C}^{*}=34.4\right)$ and brighter, and in the $3 / 4$ ripe stage, where fruits displayed an angle hue approaching orange $(h o=75.3)$ with a chromaticity of $\left(\mathrm{C}^{*}=\right.$ 43.4) and enhanced brightness ( $\left.\mathrm{L}^{*}=50.3\right)$. Colour changes in plum could be related to a decrease in chlorophyll levels and an increase in carotenoid biosynthesis. Soluble solids (SS) significantly increased from the green stage $\left(5.8^{\circ}\right.$ Brix) to the ripe stage $\left(23.9^{\circ}\right.$ Brix). Alia-Tejucal et al. (2012) reported maximum values of $17.3^{\circ}$ Brix after 67 harvestings. Elsewhere, Montalvo-González et al. (2011) and Tiburski et al. (2011) found SS for yellow plums varied between $14.9^{\circ}$ Brix to $15.0^{\circ}$ Brix. An increase in the SS as fruit ripening progressed has been reported by several authors (Dantas et al., 2016; Bautista-Banos et al. 2003; Perez et al. 2004; Osuna et al. 2011). Titratable acidity (TA), both in pulp and epicarp, was higher in the green stage and significantly decreased as the fruit ripened from $0.48 \%$ to $0.27 \%$ in pulp and from $0.42 \%$ to $0.23 \%$ in the epicarp (Vargas et. al. 2017). These results are in support with those reported by Dantas et al. (2016), Díaz-Pérez et al. (1999), Filgueiras et al. (2001) and Pérez et al. (2004) who got a decrease of titratable acidity as fruit ripening progressed. Alia-Tejacal et al. (2012) obtained values between 0.2 and $2.0 \%$ citric acid, while Tiburski et al. (2011) reported values of $1.46 \%$ of citric acid in yellow plum. Flavour index (FI) significantly increased with ripening both in pulp (from 12.35 to 87.62) and epicarp (from 18.47 to 105.16) (Vargas et al. 2017). The flavor index increased as a result of a decrease in TA and an increase in SS. Dantas et al. (2016), Filgueiras et al. (2001) and Pérez et al. (2004) reported a similar behavior. On the contrary, Alia-Tejucal et al. (2012) confirmed a high variation on the FI (3.0 to 63.2) which they attributed to the wide genetic diversity of the evaluated fruits.

The $1 / 2$ green and the $3 / 4$ ripe fruit stages contained higher total phenols concentrations in the pulp, 89.21 and 77.7 mg GAE $100 \mathrm{~g}^{-1}$ respectively, compared to the green and fully ripe stages (Vargas et al., 2017). However, the fully ripe stage showed the highest total phenols concentration in the epicarp (190.6 mg GAE $\left.100 \mathrm{~g} \mathrm{~g}^{-1}\right)$. Filguerias et al. (2001) quantified the highest concentration of total phenols in the ripe stage of Spondias purpurea and obtained values between 160 and $240 \mathrm{mg} \mathrm{GAE} 100 \mathrm{~g} \mathrm{~g}^{-1}$. Vieira et al. (2011) reported total phenols in plums of

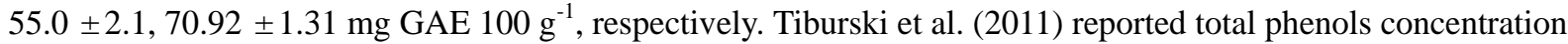
in pulp of yellow plum (Spondias mombin) of $260 \mathrm{mg}$ GAE $100 \mathrm{~g}^{-1}$. In the case of Mexican plum 'Cuernavaqueña', both the pulp and the epicarp are consumed, therefore the sum of the total phenol concentration of the pulp and the epicarp in ripe fruit make approximately $239 \mathrm{mg}$ GAE $100 \mathrm{~g}^{-1}$ (Vargas et al., 2017). Phenols in Spondias purpurea have a natural antioxidant function and its consumption provides benefits against chronic and degenerative diseases (Filguerias et al., 2001; Tiburski et al., 2011). Flavonoids concentration in the pulp significantly increased from the green stage to the $3 / 4$ ripen and the fully ripe stages, from 17 to 23-22 mg QE $100 \mathrm{~g}^{-1}$ (Vargas et al., 2017). They indicated that the highest concentration of total flavonoids was observed in the epicarp of ripe plums with $214 \mathrm{mg} \mathrm{QE} 100 \mathrm{~g} \mathrm{~g}^{-1}$. The total flavonoids content in ripe Mexican plum 'Cuernavaqueña' when the pulp and the epicarp flavonoids concentrations were added resulted in a total of approximately $245 \mathrm{mg} \mathrm{QE} 100 \mathrm{~g}^{-1}$ which is higher than the content reported for papaya (63.2 mg QE $\left.100 \mathrm{~g}^{-1}\right)$, grape (55.9 mg EQ $\left.100 \mathrm{~g}^{-1}\right)$, açaí (70.1 mg QE $\left.100 \mathrm{~g}^{-1}\right)$ and strawberry (21.8 mg QE 100 $\left.\mathrm{g}^{-1}\right)$ (Zielinski et al., 2014). 


\subsection{Maturity Indices and Quality Components}

The stage of maturity at which chili plums are harvested impacts significantly on their ultimate flavour and shelf life. Harvest maturity has a direct effect on the fruits' flavour components, physiological deterioration, susceptibility to physical injuries, resistance to moisture loss, susceptibility to invasion by rot organisms, market life and ability to ripen (Mohammed, 2015). Maturity of chili plums is determined by skin colour changes and fruit size and shape. Chili plums are usually classified as immature dark green (MI), mature light green (M2), slightly turning (light cream yellow) or breaker (M3) and tree ripe (uniform yellow) (M4). Immature dark green (M1) fruits may fail to ripen or ripen abnormally (Bridgemohan, 2008; Bridgemohan \& Mohammed, 2019)). Apart from being highly prone to physical damages, immature fruits lack a fully developed surface cuticle thereby increasing their susceptibility to moisture loss. Immature chili plums have the lowest total soluble solids content and the highest acids compared to other stages of fruit maturity. Mature green (M2) and breaker (M3) fruits, moreso the latter than the former, are ideal as a fresh fruit desert or for processing into sweet or sour pickles and are also associated with a higher level of consumer acceptance. At different stages of maturity, fruits are consumed fresh, frozen, or processed into diverse food products such as pickles and candies. In situ tree ripen fruits (M4) which have the highest level of consumer acceptance also have a shortened shelf life due to flesh softening which render them conducive to, physical damage, bird damage and secondary microbial infections. Usually, by the time M4 fruits reach the consumer they become overripe, with poor eating quality and high postharvest losses (Bridgemohan, 2008).

\subsection{Pre-harvest Factors Affecting Fruit Quality}

Maintaining the nutritional status is an important factor in quality evaluation of chili plums at harvest and during storage. Excessive nitrogen application to the plant delays fruit maturity, induces poor colour development, and inhibits ground colour change from green to yellow. However, nitrogen soil deficiency leads to small fruit development accompanied by poor flavour and unproductive trees (Barbeau, 1994; Bridgemohan \& Mohammed, 2019).

Since the chili plum seeds are not fertile, the plant is mainly propagated through large cuttings, $60-180 \mathrm{~cm}$ long and selection of cuttings is based on the most vertical new growths 1-2 years old, at the end of the dry season. However excess water at planting time could jeopardize plant growth as the wounds do not heal causing the cuttings to rot. With this technique, production begins the following year, climaxing after 4-5 years (Barbeau, 1994; Bridgemohan \& Mohammed, 2019).

Ripe chili plums are highly vulnerable to fruit flies (Anastrepha spp). Other important pests include mites and birds. Fungal attacks are another limitation as infested fruits become covered with a grey ash-like dust which also spreads rapidly along the branches thereby reducing fruit size, appearance, taste, flavour and overall marketability and display quality (Barbeau, 1994, Bridgemohan, 2008).

\subsection{Postharvest Management Affecting Quality}

\subsubsection{Temperature Management}

Management of fruit temperature and relative humidity is paramount for extending the shelf life of fresh chili plums. Removal of field heat following harvest could be expedited by room cooling $\left(9-10^{\circ} \mathrm{C}, 85-95 \%\right.$ r.h $)$ or by hydrocooling. Chili plums should be stacked in the refrigerated rooms with air spaces between pallets and room walls to ensure good air circulation. Transit vehicles must be cooled before loading the fruits. Delays between cooling after harvest and loading into transit vehicles should be avoided. Maintaining the cool chain throughout the handling system is essential to optimize quality and shelf life (Mohammed, 2015).

\subsubsection{Physical Damage}

Chili plums have a thin skin and are eaten with the skin intact. Physical injuries resulting from abrasions due to over packing, punctures arising from sharp protrusions within harvesting containers or directly from harvesters' finger nails or from impact and vibration bruising during transportation and distribution must be controlled and reduced. Such physical injuries compromise fruit appearance, accelerate water loss, provide sites for fungal and bacterial invasion and stimulate respiration and ethylene production (Mohammed, 2015).

\subsubsection{Transpiration}

Fresh weight losses in chili plums is related to stage of maturity at harvest, storage temperature and storage duration. Graham et al. (2001) reported that immature fruits had higher percentages fresh weight losses irrespective of storage temperature and duration than mature green and turning or breaker fruits. This could be attributed to differences in cuticular thickness of the epidermal epicarp which offered more protection against 
moisture losses as fruit maturity progressed. Graham et al. (2001) also demonstrated that fruits stored at $20-21^{\circ} \mathrm{C}$ and $30-31^{\circ} \mathrm{C}$ exhibited more moisture losses compared to fruits stored at $4-5^{\circ} \mathrm{C}$ and $9-10^{\circ} \mathrm{C}$. They implied that this is due greater respiratory activity at the higher versus lower storage temperature. However, chili plums regardless of temperature and stage of maturity showed accelerated increases in percentage fresh weight losses as storage time advanced. Chili plum fruits with higher percentages fresh weight losses appeared to have a rougher skin surface rather than shriveled surface. These were notably less juicy, with thinner edible epicarps (Figure 2).

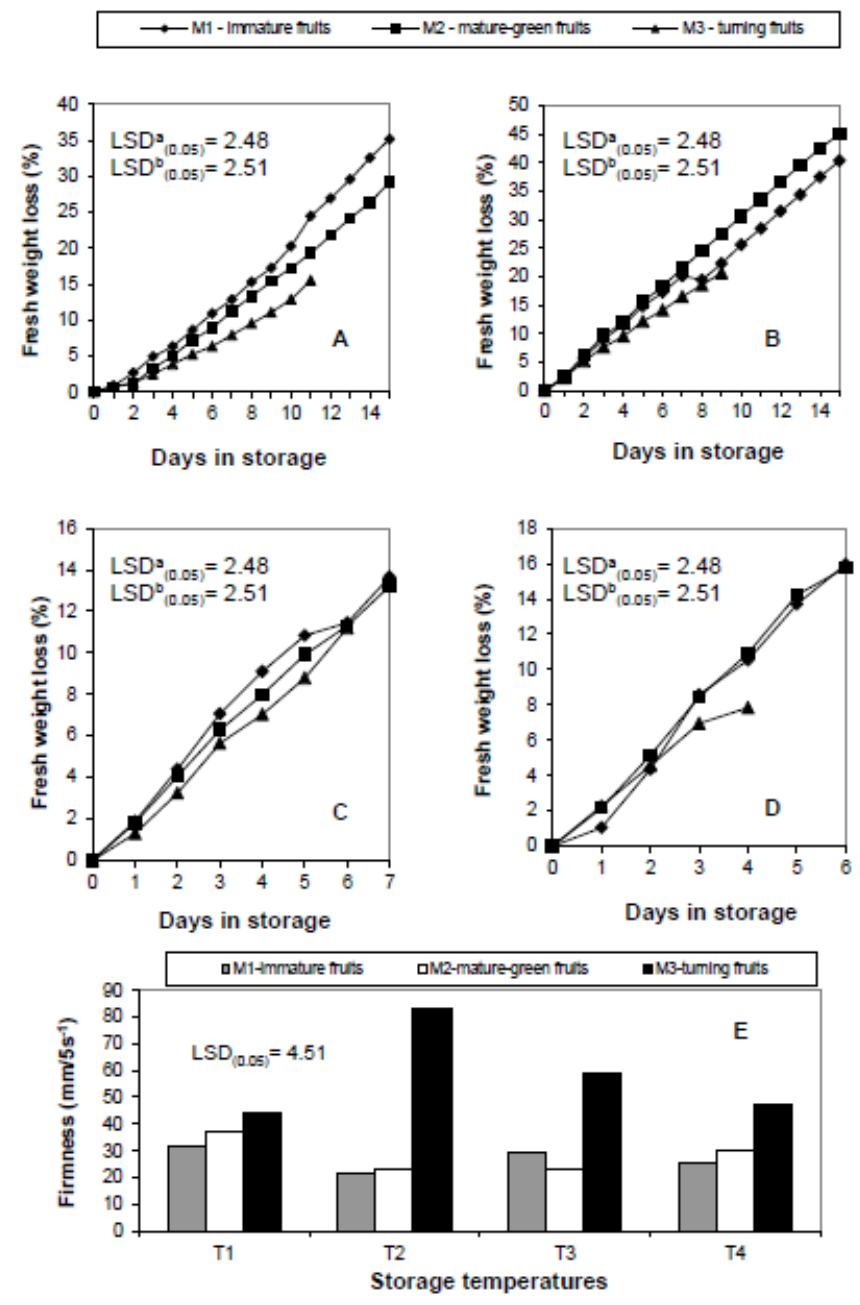

Figure 2. Changes in fresh weight losses and firmness of chili plums during storage

(A) Fruits stored at $4-5^{\circ} \mathrm{C}$, (B) fruits stored at $9-10^{\circ} \mathrm{C}$, (C.) fruits stored at $20-21^{\circ} \mathrm{C}$, (D) fruits stored at $30-31^{\circ} \mathrm{C}$ and (E) firmness. LSD: over time ${ }^{\mathrm{a}}$ while across maturity stages and temperatures on the same day ${ }^{\mathrm{b}}(\mathrm{Graham}$ et al., 2001)

\subsubsection{Atmosphere}

Notable benefits were obtained as a result of the modified atmosphere created within the sealed packages when chili plums were packaged in low density polyethylene (LDPE) or high density polyethylene bags and stored under refrigerated conditions. The high relative humidity surrounding fruits in the saturated moisture environment within sealed packages led to a reduction in fruit weight losses and chilling injury symptoms development while enhancing overall appearance. Accordingly, fruits acquired a longer shelf life and were marketed over longer periods. Evidently, the fruits had a more acceptable taste, were juicier, firmer with thicker epicarps. (Graham et al., 2001). 


\subsection{Physiological Disorders}

\subsubsection{Chilling Injury (CI)}

Chili plums are very sensitive to storage under refrigerated conditions (Avitia-García et al., 2000; Mohammed, 2015). Chilling injury alters the function of plasma membranes and their associated enzymes, as well as the general metabolic activities of cells (Maldonado-Astudillo et al., 2014). Graham et al. (2001) stored fruits at three different stages of maturity under refrigerated conditions. They reported chilling injury symptoms such as skin pitting in fruits at the immature green, mature green and turning or breaker when fruits were stored at $4-5^{\circ} \mathrm{C}$ and to lesser extent at $9-10^{\circ} \mathrm{C}$, after 4 days only. Pitting was extensive in the immature green fruits and least in the turning or breaker fruits. Mature-green fruits kept at $9-10^{\circ} \mathrm{C}$ for 15 days and subsequently transferred for 2 days at $20-21^{\circ} \mathrm{C}$ had moderate chilling injury damage. Immature green fruits on the other hand, showed severe $\mathrm{CI}$ damage. Mature green fruits stored continuously for 15 days at $4-5^{\circ} \mathrm{C}$ and then transferred to $20-21^{\circ} \mathrm{C}$ for 1 day had severe CI symptoms with tiny pits coalescing into larger depressed areas with a definite brown discolouration. Similar occurrences were noted in mature green fruits stored at $9-10^{\circ} \mathrm{C}$ for 15 days upon subsequent transfer to $20-21^{\circ} \mathrm{C}$ for 2 days.

\subsubsection{Other Physiological Disorders}

Chili plum fruits are receptive to heat injury when exposed to temperatures over $35^{\circ} \mathrm{C}$ for extended periods. Heat injury symptoms include development of scalds accompanied with surface discolouration and water-soaked translucent epicarps. Usually fruits would show symptoms of heat injury with the presence of hard lumps of unripen flesh directly underneath the skin (Mohammed, 2002; 2015).

\subsubsection{Pathological Damage}

Graham et al. (2001) reported that the shelf life of chili plums stored at $20-21^{\circ} \mathrm{C}$ and $30-31^{\circ} \mathrm{C}$ were terminated by decay after 8 days, with the incidence of decay being more prevalent and rapid in mature green and breaker fruits compared to immature green fruits (Table 1). The major cause of fruit decay was attributed to stem end rot caused by a fruit-rot fungus of the Phoma species. In another experiment Graham et al. (2001) stated that fruits stored at $30-31^{\circ} \mathrm{C}$ ripened in 3-4 days and remained marketable for an additional 2 days, beyond which fruits were completely decayed.

While fruits stored at $15^{\circ} \mathrm{C}$ and $12.5^{\circ} \mathrm{C}$ initiated ripening after 10 days, excessive softening was obtained eventually resulting in decay amounting to $65 \%$. Fruits stored at $12.5^{\circ} \mathrm{C}$ maintained a dark-green skin colour without evidence of decay up to 14 days. During this period fruits had a TSS of $11 \%$ and were still firm. Upon transfer to $30-31^{\circ} \mathrm{C}$ for 4 days following 14 days of storage at $12.5^{\circ} \mathrm{C}$ fruits ripened uniformly and were highly acceptable according to organoleptic evaluations.

Table 1. Interaction effects of day $\mathrm{x}$ temperature $\mathrm{x}$ maturity on decay incidence of chili plums stored for 8 days at $20-21^{\circ} \mathrm{C}$ and $30-31^{\circ} \mathrm{C}$

\begin{tabular}{lllllll}
\hline \multirow{2}{*}{$\begin{array}{l}\text { Storage duration } \\
\text { (days) }\end{array}$} & \multicolumn{6}{c}{ Decay $(\%)$} \\
\cline { 2 - 7 } & \multicolumn{3}{c}{$20-21\left({ }^{\circ} \mathrm{C}\right)$} & \multicolumn{4}{c}{$30-31\left({ }^{\circ} \mathrm{C}\right)$} \\
\cline { 2 - 7 } 4 & $\mathrm{M} 1$ & $\mathrm{M} 2$ & $\mathrm{M} 3$ & $\mathrm{M} 1$ & $\mathrm{M} 2$ & $\mathrm{M} 3$ \\
\hline 5 & $0.0 \mathrm{a}^{\mathrm{x}}$ & $0.0 \mathrm{a}$ & $13.3 \mathrm{ab}$ & $0.0 \mathrm{a}$ & $20.0 \mathrm{bc}$ & $13.3 \mathrm{ab}$ \\
6 & $0.0 \mathrm{a}$ & $0.0 \mathrm{a}$ & $13.3 \mathrm{ab}$ & $6.7 \mathrm{a}$ & $20.0 \mathrm{bc}$ & $26.7 \mathrm{c}$ \\
7 & $13.3 \mathrm{ab}$ & $13.3 \mathrm{ab}$ & $40.0 \mathrm{~d}$ & $53.3 \mathrm{e}$ & $73.3 \mathrm{f}$ & $86.7 \mathrm{~g}$ \\
8 & $46.7 \mathrm{de}$ & $73.3 \mathrm{f}$ & $86.7 \mathrm{~g}$ & $100 \mathrm{~h}$ & $100 \mathrm{~h}$ & $100 \mathrm{~h}$ \\
& $100 \mathrm{~h}$ & $100 \mathrm{~h}$ & $100 \mathrm{~h}$ & $100 \mathrm{~h}$ & $100 \mathrm{~h}$ & $100 \mathrm{~h}$ \\
\hline
\end{tabular}

${ }^{\mathrm{x}}$ Means followed by the same letter(s) are not significantly different $(\mathrm{P}<0.05)$. M1 = immature fruits, $\mathrm{M} 2=$ mature-green fruits and M3 = turning fruits. Graham et al. (2001).

\subsubsection{Insect Pests and Their Control}

A major threat to the expansion of chili plums as a fresh fruit regionally and extra regionally is the high susceptibility to the Caribbean fruit fly (Anastrepha spp.) (Barbeau,1994). Graham et al. (2001) found live fruit fly larvae in chili plums subjected to a hot water treatment at $45^{\circ} \mathrm{C}$ for 10 and 15 minutes respectively after 6 days of storage at $20-21^{\circ} \mathrm{C}$. Their investigation showed that while live larvae of variable sizes were found in control fruits, the larvae in heat-treated fruits at $45^{\circ} \mathrm{C}$, for 10 and 15 minutes were smaller. Dead larvae and eggs were detected in fruits treated at $45^{\circ} \mathrm{C}$ for 20 minutes and at $50^{\circ} \mathrm{C}$ for 10,15 and 20 minutes respectively. However, the heat treatment at $45^{\circ} \mathrm{C}$ for 20 minutes was more successful than the $50^{\circ} \mathrm{C}$ regime since the former 
accounted for no heat injury symptoms as opposed to the latter treatment where scalding manifested as brown coloured necrotic lesions (bronzing) dominated the surface of affected chili plum fruits.

\subsection{Postharvest Handling Practices}

\subsubsection{Harvest Operations}

The harvesting of fruits at physiological maturation to stimulate the process of ripening is essential in order to avoid potential losses during storage and market display (Bautista-Banos et al., 2003; Vanegas, 2005). When harvested at an unripe stage, the fruits may experience deleterious changes in colour and firmness, and they will typically fail to develop any of the optimal quality characteristics so important for commercialization (Mohammed, 2015). On the other hand, when fruits are harvested during the half-ripe stage they will usually tolerate longer periods of storage, while at the same time, achieve a quality that is both acceptable to consumers and is similar to the one attained by fruits that were allowed to ripen completely on the plant (Pérez et al., 2004; Souza, 2008). Chili plums fruits are borne in clusters and fruits in any one cluster may differ in maturity due to intra-plant competition for assimilates (Bridgemohan and Mohammed, 2019). The stem end of each fruit is attached with a fragile and extended pedicel. Harvesting of fruits is normally conducted manually in order to select fruits at physiological maturity. The abscission layer becomes weakened as the fruit begins to turn and upon ripening it is easily dislodged by strong winds and birds (Bridgemohan \& Mohammed, 2019). The fragile nature of the pedicel induces physical damages at the stem ends during harvesting operations, eventually resulting in stem end rots and multiple infections, particularly when the severity of injuries is associated with split stem ends, rupturing of the pericarp and release of substrates. Abrasions, microscopic punctures and compression damages also accompany fruits during harvesting and are sites for secondary infections. Harvested fruits should be packed in well ventilated, shallow, light coloured containers to optimize quality and reduce postharvest losses associated with physical damages outlined above. Fruits should be placed in shaded environments during delays between harvest and transport to the packinghouse in order to minimize heat stress (Bridgemohan \& Mohammed, 2019).

\subsubsection{Packinghouse Practices}

Due to the climacteric nature of chili plums, fruits must be pre-cooled to remove field heat via room cooling or hydrocooling. It is imperative that fruits are washed in chlorinated water (100-150 ppm) followed by a rinse and air drying. Fruits placed on packing lines should be equipped with conveyor belts that are well-padded to minimize bruising. Sorting and grading must be exercised prior to packaging to attain uniformity in size and fruit maturity to suit market requirements. Sanitation protocols must be monitored and implemented throughout all packinghouse operations. Since fruits are eaten with the unpeeled skin every effort must be made to ensure they are sufficiently sanitized to eliminate occurrences of food borne diseases (Mohammed, 2015).

\subsubsection{Control of Ripening and Senescence}

Changes from the typical green skin colour to a light yellow colour as well as the reduction of flesh firmness are the best visual indicators of chili plum fruit ripening and is a good predictor of potential shelf life (Mohammed, et al., 2016; Bridgemohan \& Mohammed, 2019). Changes in skin colour and flesh firmness are directly related to the stage of maturity at harvest and controlled by temperature. Mature green and breaker stage fruits will ripen properly without exogenous ethylene application. Generally, ethylene application to fruits harvested at the turning or breaker stage will only ripen the fruit more uniformly without speeding up the rate of ripening. Adequate air circulation and maintaining a relative humidity of $90-95 \%$ are recommended to achieve uniform fruit temperature and prevention of fruit shriveling during the ripening process (Mohammed et al., 2016). Physiologically mature fruits stored at $28-30^{\circ} \mathrm{C}$ would ripen in $3-4$ days whereas at $15-17^{\circ} \mathrm{C}$ would ripen in $10-11$ days. At even lower storage temperatures at $9-10^{\circ} \mathrm{C}$ it would require $14-15$ days for full ripening. However, storage of fruits at $4-5^{\circ} \mathrm{C}$ would extend shelf life up to 15 days but chilling injury and decay would occur. Graham et al. (2001) indicated that chili plums could be successfully stored up to 14 days at $12.5^{\circ} \mathrm{C}$ and when fruits are subsequently transferred to $30-31^{\circ} \mathrm{C}$ fruits ripened normally with an additional shelf life of 4 days. Mohammed $(2002 ; 2016)$ found that chili plums harvested or taken from storage where ripening was already initiated (breaker) would tolerate chilling temperatures of $5-6^{\circ} \mathrm{C}$ and maintain good organoleptic quality (Figure $3)$.

Effects of 1-methylcyclopropene (1-MCP) on the shelf life and the quality of Mexican plums were investigated by Garcia et al. (2011). 1-MCP was applied at 100, 200 or $300 \mathrm{~nL} \mathrm{~L}^{-1}$ for 12 hours at ambient temperature inside sealed experimental chambers of $0.512 \mathrm{~m}^{3}$, and compared to an untreated control. After the 1-MCP application, fruits were stored under simulated marketing conditions $\left(22 \pm 2{ }^{\circ} \mathrm{C} ; 70 \pm 10 \% \mathrm{RH}\right)$ up to 9 days. 1-MCP at rates of 100,200 or $300 \mathrm{~nL} \mathrm{~L}^{-1}$ were able to extend shelf life and to maintain the quality of Mexican plum yellow 
fruits up to 3 additional days compared to the control, thus achieving 9 and 7 days of shelf life for ripe and $3 / 4$ ripe fruits, respectively. 1-MCP decreased the respiration rate and the weight loss of ripe fruits, but not in $3 / 4$ ripe fruits. 1-MCP delayed also the development of external colour and maintained fruit firmness, without affecting its total soluble solids content.

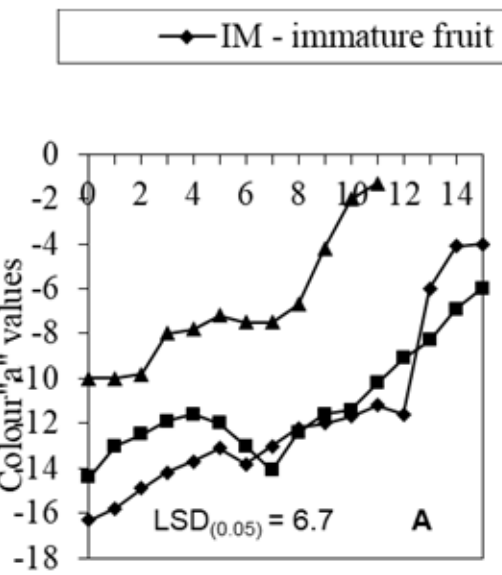

Days in storage

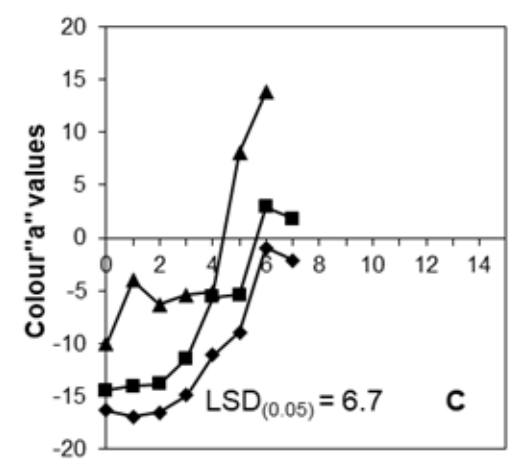

Days in storage

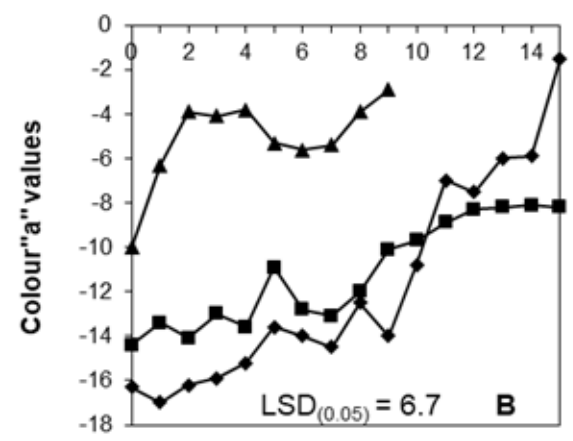

Days in storage

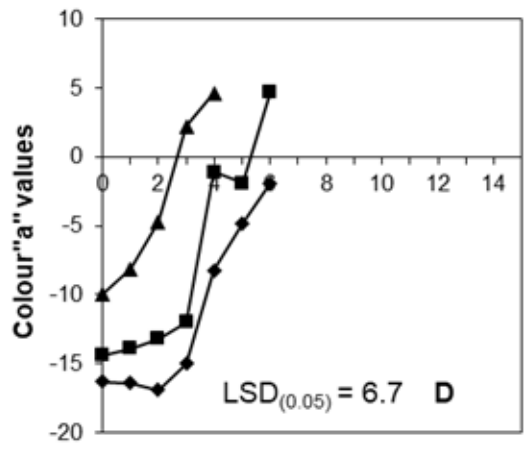

Days in storage

Figure 3. Colour changes ("a" values) in chili plums stored for 15 days

(A) Fruit stored at $4^{\circ} \mathrm{C}$, (B) fruit stored at $9^{\circ} \mathrm{C}$, (C.) fruit stored at $20^{\circ} \mathrm{C}$ and (D) fruit stored at $30^{\circ} \mathrm{C}$. Level of significance $(\mathrm{P}<0.001)$ (Graham et al., 2001).

\subsubsection{Storage and Shipping Conditions}

Chili plum fruits harvested at full mature or slightly turning with a light yellow skin colour, that are blemish-free and subjected to a hot water treatment at $45^{\circ} \mathrm{C}$ for 20 minutes should be selected for overseas markets. Prior to shipment, fruits should be stored in shallow, ventilated one-ply cardboard cartoons at $12.5^{\circ} \mathrm{C}$ and $90-95 \%$ relative humidity. These conditions should be maintained throughout shipment for a maximum 7-8 days to allow display at overseas retail outlets at $20-22^{\circ} \mathrm{C}$ for another 4-6 days (Mohammed 2002). At display outlets fruits could be repackaged into smaller portion sizes in sealed low density polyethylene bags in order to achieve marketable fruits of over 90-95\% (Mohammed, 2002, 2016).

\subsection{Processing}

\subsubsection{Fresh-cut Processing}

Fresh-cut technology has only been applied at the cottage level where slits are made with a knife at 2-3 locations on the fruit flesh and then sprinkled with salt and pepper as an appetizer or snack. Seal-packaged with 10-15 fruits per bag (LDPE), these snacks are popular at bazaars, cafeterias, sport events and other public functions as 
ready-to-eat items. Alternatively, some vendors would make longitudinal face slices on either side of each fruit and serve with other fresh-cut fruits in stretch-wrapped styrofoam containers. Fresh-cut chili plums are also used as a stuffing in baked or curried fish (Mohammed, 2002).

\subsubsection{Other Processing Practices}

The processing and utilization of chili plums into a diverse range of value-added products were extensively investigated and described by Sammy (1994). Chili plums selected at the mature green and ripe stages were transformed into high sugar products, such as jams, jellies, fruit cheeses, preserves, candies, cordials and squashes. Value-added food products such as salted pickles, canned in brine and in sauces were also articulated by Sammy (1994). Other processing initiatives included production of fermented items such as wines and yogurt derived from ripe fruits, as well as dried and dehydrated products either whole or in slices (Sammy, 1994) all of which are currently manufactured in several cottage industries throughout the Caribbean. For the high sugar products, a concentration of $60-70 \%$ sugar is required, which through its osmotic effect, prevented microbial spoilage. For high salted products, the fruits were immersed in pure, granulated uniodized salt (1-3\%) for flavour, plus vinegar containing 4-6\% acetic acid for flavour and preservation purposes. Salt (2.5-8\%) was also used as a selective agent facilitating the growth of lactic acid bacteria during the preparation of fermented chili plum pickles. For fermented chili plum pickles, mature green fruits sanitized in a chlorine dip (50ppm) were allowed to ferment for 2-3 weeks in a brine solution made up of $25-50 \mathrm{~g}$ salt and $50 \mathrm{ml}$ vinegar per litre of water. The fermented plums were submerged in fresh brine and flavoured and acidified. The final stage involved pasteurizing at $85^{\circ} \mathrm{C}$ for $15-20$ minutes or by using a combination of chemical preservation with sodium benzoate $(0.1 \% \mathrm{w} / \mathrm{w})$ or potassium sorbate $(0.1 \% \mathrm{w} / \mathrm{w})$ or potassium metabisulphite $(0.03 \% \mathrm{w} / \mathrm{w})$ and pasteurization (Sammy, 1994). For dried and dehydrated products Sammy (1994) identified the use of fully mature, ripe firm fruits to be blanched for 5-15 seconds in boiling sodium hydroxide (10-20 $\left.\mathrm{g} \mathrm{l}^{-1}\right)$ to roughen the skin and accelerate the drying procedure. This was followed by dipping the treated fruits for 10-15 minutes in a $0.5 \%$ sodium metabisulphite solution $\left(5 \mathrm{gl}^{-1}\right)$ to induce preservation and prevent brown discolorations. Afterwards, fruits were then soaked for 12-18 hours in a sugar solution containing two parts of sugar and one part of water by weight to withdraw moisture out of the fruit via osmosis and then dried to a moisture content of 12-14\% (Sammy, 1994).

\subsection{Medicinal Benefits and Ago Industrial Waste Utilization}

In their studies, Vargas-Simon (2018) confirmed the climacteric pattern of respiration and further explored the nutraceutical values and medicinal potential of the plum Spondias purpurea. Vargas-Simon (2018) claimed that fruits have diuretic and antispasmodic properties and are commonly used as an antihistaminic. The extract from the tree bark is recommended for stomach upset such as dysentery, among other conditions. It has a strong larvicidal activity; the endocarp, seminal coat, and seed have significant amounts of cellulose, useful for phosphate ions flocculation from wastewaters.

\section{Conclusion}

The highly perishable nature coupled with very short seasonality of production, are major challenges confronting the availability and marketing of fresh chili plums. The low flesh to seed ratio makes it imperative to select only fruits at the mature green and breaker or turning stages of maturity for consumption as a fresh fruit or utilization into value-added products. Temperature management supplemented with atmospheric control to reduce or alleviate chilling injury damages and at the same time ensure proper ripening and optimum eating quality are achievable. As a potential export fruit, the use of hot water or hot moist air treatments must be explored to counteract problems associated with fruit fly infestations. The significance of enzymes on fruit softening warrants further investigation in order to counteract the rapidity of textural changes during ripening. Obtaining suitable packaging requirements to reduce physical damages would be beneficial in order to secure the best quality fruit for development into value-added product.

\section{References}

Adepoju, O. T. (2009). Proximate composition and micronutrient potentials of three locally available wild fruits in Nigeria. African Journal Agric. Res., 4(9), 887-892.

Alia-Tejacal, I., Maldonado-Astudillo, Y. I., Núnez-Colín, C. A., Valdez-Aguilar, L. A., Bautista-Banos, S., García-Vázquez, E., Ariza-Flores, R., \& Rivera-Cabrera, F. (2012). Caracterización de frutos de Ciruela Mexicana (Spondias purpurea L.) del sur de México. Rev. Fitotec. Mexico, 35, 21-26.

https://www.researchgate.net/publication/254560313.

Avitia-García, E., Castillo-González, A.M. \& Pimienta-Barrios, E. (2000). Ciruela Mexicana y otras especies del 
género Spondias letua. Universidad Autónoma de Chapingo. Primera edición, México, pp. 75. https://doi.org/10.1016/j.scienta.2014.05.016.

Barbeau, G. (1994). 'Plums'. Proceedings of the Third Regional Workshop on Tropical fruits, Grenada, 131-134.

Bautista-Banos, S., Díaz-Pérez, J. C., Barrera-Necha, L. L.\& Bravo-Luna, L. (2003). Postharvest study of red mombin (Spondias pupurea) fruit during storage. Revista Iberamericana de. Tecnología Postcosecha, Hermosillo, Postcosecha, 5(2), 82-85. https://doi.org/10.1016/j.cropro.2005.03.010

Bora, P. S., Narain, N., Holschuh, H. J. \& Vasconcelos, M. A. S. (1991). Changes in physical and chemical composition during maturation of yellow mombin (Spondias mombin) fruits. Food Chem., 41(3), 341-348. https://doi.org/10.1016/0308-8146(91)90058-V

Bridgemohan, P., \& Mohammed, M. (2019). The Eco-physiology of Abiotic and Biotic Stress on the pollination and Fertilization of cacao (Theobroma cacao L.; formerly Sterculiaceae family). Biotic and Abiotic Stress in Plants, Ed. Alexnadre De Olivera, University of Florida, USA.

Bridgemohan, P., \& Isaac, W. P. (2017). Postharvest handling of Indigenous and Underutilized Fruits in the Caribbean. Postharvest Handling.

Bridgemohan, P. (2008). Incubator Farms as a Sustainable Approach for 'Neo Farmers'. Conference Presentation, Caribbean Food Crops Society, 44th Annual Meeting, Miami, Florida, USA. Retrieved from https://ageconsearch.umn.edu/record/256455

Coombe, B. G. (1976). The development of fleshy fruits. Annual Review in Plant Physiology, 27, 207-228. https://doi.org/10.1146/annurev.pp.27.060176.001231.

Cuevas, J. A. (1994). Spanish plum, red mombin (Spondias purpurea). In: Hernando Bermejo, J. E., Leon, J. (Eds.), Neglected crops: 1492 from a Different Perspective. Plant Production and Protection, Series no. 26 (pp. 111-115). Food and Agriculture Organization, Rome, Italy. https://doi.org/10.3732/ajb.93.12.1757

Dantas, L. A., Silva, D. M. S., Dantas, L. R., De Sousa, B. S. A., \& Schunemann, P. P. A. (2016). Development physiology of maturation and indication of harvest point of Umbuguela tree fruits (Spondias sp.). Revista Brasileira de Fruticultura, Jaboticabal, 38(1), 33-42. https://doi.org/10.1590/0100-2945-271/14

Diaz-Perez, J. C., Zavaleta, R., Bautista, S., Aguilar, B., \& Sebastian, V. (1999). Cambios físico-químicos de ciruela mexicana (Spondias purpurea L.) cosechada en dos diferentes estados de madurez. Revista Iberoamericana de Tecnología Postcosecha, Hermosillo, 1(1), 19-24.

Engels, C., Grater, D., Esquivel, P., Jiminez, V. M., Ganzle, M. G., \& Schieber, A. (2012). Characterization of phenolic compounds in jocote (Spondias purpurea L) peels by ultra-high performance chromatography/electrospray ionization mass spectrometry. Food Res. Int., 46, 557-562. https://doi.org/10.1016/j.foodres.2011.04.003

Filgueiras H. A. C., Alves E. R., \& Araújo M. C (2001), 'Quality of fruits native to Latin American Industry: Jobo (Spondias mombin L), Proceedings of International Society for Tropical Horticulture, 43, $72-76$.

García, J. A. O., Barraza, M. H. P., Valdivia, V. V., \& Jaimez, R. G. (2011). Application of 1-methycyclopropene on Mexican plum (Spondias purpurea L.). Rev. Fitotec. Mex., 34(3), 197-204. https://www.researchgate.net/deref/http3D61019746007

Graham, O., Wickham L. D., \& Mohammed, M. (2001). Respiration and ethylene production rates of chili plums (Spondias purpurea L) during storage, Proceedings of the $37^{\text {th }}$ Annual Meeting of Caribbean Food Crops Society, 37, 243-251.

Guthrie, H. A. (1979). Introductory nutrition, $4^{\text {th }}$ ed. In: The C.V. Mosby Company, St. Louis, MO, USA.

Hamano, P. S., \& Mercadante, A. Z. (2001). Composition of carotenoids from commercial products of caja (Spondias lutea). J. Food Compos. Anal., 14, 335-343. https://doi.org/10.1006/jfca.2000.0975

Hiwasa-Tanase, K., \& Ezur, H. (2014). Climacteric and non-climacteric ripening. In: Fruit Ripening, Physiology, Signaling and Genomics, (Eds. P. Nath et al., CABI International, USA, 2014), Chap. 1. pp. 1-14. https://doi.org/10.1079/9781845939625.0001

Hooper, L., \& Cassidy., A. (2006). A review of the health care potential of bioactive compounds. Journal of the Science of Food and Agriculture, London, 86(12), 1805-1813. https://doi.org/10.1002/jsfa.2599

Isabelle, M., Lee, B. L., Lim, H. T., Koh, W. P., Huang, D., \& Ong, C. N. (2010). Antioxidant activity and profiles of common fruits in Singapore. Food Chemistry, London, 123(4), 77-84. 
https://doi.org/10.1016/j.foodchem.2010.04.002

Hooper, L., \& Cassidy, A. (2006). A review of the health care potential of bioactive compounds. Journal of the Science of Food and Agriculture, 86(12), 1805-1813. https://doi.org/10.1002/jsfa.2599

Isabelle, M., Lee, L. L., Lim, M. T., Koh, W. P., Huang, D., \& Ong, C. N. (2010). Antioxidant Activity and profiles of common fruits in Singapore, Food Chemistry, 123(1), 77-84.

Kader, A. A. (1986). Biochemical and physiological basis for effects of controlled and modified atmosphere on fruits and vegetable. Food Technology, 5(1), 99-104. http://dx.doi.org/10.4236/wjet.2016.42015.

Koziol, M., \& Macía, M., (1998). Chemical composition, nutritional evaluation and economic aspects of Spondias purpurea (Anacardiaceae). Economic Botany, 52(4), 373-380. https://doi.org/10.1007/BF02862067

Leung, W. T. W., \& Flores, M., (1961). Tabla de composición de alimentos para uso en América latina, National Institutes of Health, Bethesda, MD, USA. Retrieved from www.researchgate.net/publication/44731281

Macia, M. J., \& Barfod, A. (2000). Economic botany of Spondias purpurea Anacardiaceae in Ecuador. Economic Botany, 54(4), 449-458. https://doi.org/10.1007/BF02866544

Maldonado-Astudillo, Y. I., Alia-Tejacal, I., Núñez-Colín, C. A., Jiménez-Hernández, J., López-Martínez, V., Valle-Guadarrama, S., A... Pelayo-Zaldívar, C. (2014). Postharvest physiology and technology of Spondias purpurea L. and S. mombin L., Sci. Hortic., 174, 193-206. https://doi.org/10.1016/j.scienta.2014.05.016

Mitchell, J. R., Buckley, K., \& Burrows, I. E. (1978). Food binding agent, UK Patent 1, 525 123. The Patent Office, London, England. Retrieved from www.academia.edu/11141430.

Mohammed, M., Craig, K., Mpagalile., J., \& Lopez, V. (2016). Postharvest losses in the Caribbean: Progress and Challenges in quantification, causes, solutions and economic analysis. FAO Second Regional Dialogue on Prevention and Reduction of Food Losses and Waste in Latin America and the Caribbean. Grenada, pp. 16.

Mohammed, M. (2015). Postharvest innovations and quality management strategies to reduce losses of tropical fruits and vegetables. Proceedings of the Fourth Postharvest Technology Workshop on Fruits and Vegetables, EMBRAPA, San Carlos, Brazil, pp. 19.

Mohammed, M. (2011). Chili plum (Spondias purpurea var. Lutea), In: (ed. E. M. Yahia), Postharvest Biology and Technology of Tropical and Subtropical Fruits, Chapter, 2(2), 423-436. https://doi.org/10.1533/9780857092762.423

Mohammed, M. (2002). Postharvest technology of exotic Anacardiaceae fruits, IICA Workshop on Postharvest handling of minor fruits, Grenada, 11pp.

Montalvo-Gonzalez, E., Garcia, H. S., Mata-Monte de Oca., \& Tovar-Gomez, B. (2011). Efecto de la luz en ciruela mexicana manejada en diferentes condiciones de almacenamiento. CyTA- Journal of Food, Abingdon, 39(4), 65-70. https://doi.org/10.1080/19476331003642562

Niva, M. (2007). All foods affect health: understandings of functional foods and healthy eating among health-oriented Finns. Appetite, Singapore, 48(3), 384-393. https://doi.org/10.1016/j.appet.2006.10.006

Oliveira, M. E. B., Filgueiras, H. A. C., \& Sousa, R. E. (1999). Avaliacâo de parâmetros de qualidade fisico-quimicos de polpa congelada de acerola, cajá e cajú'. Ciencia e Technologia de Alimentos, 19(3), 326-332. https://doi.org/10.1590/S0101-20611999000300006

Osuna, G. J. A., Perez, B. M. H., Vasquez, V. V., \& Gomez, J. R. (2011). Application of 1-methylcyclopropene (1-MCP) on Mexican Plum (Spondias purpurea L.). Revista Fitotecnia Mexicana, Chapingo, 34(3), 197-204.

Pareira, E. C. P., Filgueiras, H. A. C., \& Alves, R. E. (2000). Actividad respiratoria y producción de etileno postcosecha de ciruela mexicana y jobo. Revista Iberoamericana de Tecnología Poscosecha, Hermosillo, 2, 155-160.

Perez, L. A., Saucedo, V. C., Arevalo, G. M. L., \& Guratalla, L. A. (2004). Efecto del grado de madurez en la calidad y la vida postcosecha de ciruela Mexicana Spondias purpurea L. Revista Fitotecnia Mexicana, Chapingo, 27(2), 133-139.

Rodriguez-Amaya, D. B., \& Kimura, M. (2004). HarvestPlus Handbook for Carotenoid Analysis. Washington: HarvestPlus Technical Monograph Series, 2, 35-36.

Sameh, S., Al-Sayed, E., Labib, R. M., \& Singab, A. S. (2018). Genus Spondias: A Phytochemical and Pharmacological Review. Evid. Based Compliment Alternat. Medicine. 
https://doi.org/10.1155/2018/5382904

Sammy, L. (1994). Processing of West Indian cherry, guava, tamarind, plum and dunks, IICA Third Regional Workshop on Tropical Fruits, Grenada, 138-154.

Sampaio, S. A., Bora, P. S., Holschuh, H. J., \& de Melo, S. S. (2007). Postharvest respiratory activity and changes in some chemical constituents during maturation of yellow mombin (Spondias mombin) fruit, Ciencia e Technologia de Alimentos, 27(3), 1-9. https://doi.org/10.1590/S0101-20612007000300014

Sousa, M. M. B., Almeida, A. G., Fernandes, G. A., \& Maia, A. C. (2007). Magalhaes Correlação entre a atividade antioxidante e os conteúdos de vitamina $\mathrm{C}$ e fenólicos totais em frutas tropicais do nordeste brasileiro, XLVII Congresso Brasileiro de Química, 1 Natal, Brazil.

Tiburski, J. H., Rosenthal, A., Deliza, R., Godoy, R. L. O., \& Pacheco, S. (2011). Nutritional properties of yellow mombin (Spondias mombin L.) pulp. Food Research International, London, 44, 2326-2331. https://doi.org/10.1016/j.foodres.2011.03.037

Vanegas, M. J. (2005). Guia tecnica del cultivo del jocote. Programa de Nacional de Frutas de El Salvador, Ministerio de Agricultura y Ganaderia. Instituto de Interamericana Cooperation para la Agricultura la edicion. pp. 26.

Vargas, A. S., Lopez-Martinez, V., Juarez-Lopez, P., \& Perez-Flores L. J. (2017). Botanica e Fiiologia/botany and physiology antioxidant activity and physico-chemical parameters in "Cuernavaquena" Mexican plum (Spondias purpurea L.) at different ripening stages. Revista Brasileira de Fruiticultura, 39(4), 1-10. https://doi.org/10.1590/0100-29452017787

Vieira, M. L., Sousa, B. S. M., Manani-Filho, J., \& Lima, D. A. (2011). Total phenolics and antioxidant capacity "In vitro" of tropical fruit pulps. Revista Brasileira de Fruticultura, Jaboticabal, 33(3), 888-897. https://doi.org/10.1590/S0100-29452011005000099

Winton, A. L., \& Winton, K. B. (1935). The structure and composition of foods. Vegetables, legumes, fruits, John Wiley and Sons, Inc., New York, USA.

Zielinski, A. A. F., Ávila, S., Ito, V., Noriega, A., Wosiacki, G., \& Haminiuk, C. W. I. (2014). The Association between chromaticity, phenolics, carotenoids, and in vitro antioxidant activity of frozen fruit pulp in Brazil: an application of chemometrics. Journal of Food Science, Chicago, 79(4), 510-516. https://doi.org/10.1111/1750-3841.12389

\section{Copyrights}

Copyright for this article is retained by the author(s), with first publication rights granted to the journal.

This is an open-access article distributed under the terms and conditions of the Creative Commons Attribution license (http://creativecommons.org/licenses/by/4.0/). 